\title{
Aggressive Pituitary Tumors
}

\author{
Eleftherios Chatzellis Krystallenia I. Alexandraki Ioannis I. Androulakis \\ Gregory Kaltsas
}

Endocrine Unit, Department of Pathophysiology, National University of Athens, Athens, Greece

\section{Key Words}

Aggressive pituitary adenomas - Atypical adenomas . Pituitary tumors

\begin{abstract}
Pituitary adenomas are common intracranial tumors that are mainly considered as benign. Rarely, these tumors can exhibit an aggressive behavior, characterized by gross invasion of the surrounding tissues, resistance to conventional treatment leading to early and frequent recurrences. Even more rarely, pituitary tumors can give rise to cerebrospinal or systemic metastases qualifying as pituitary carcinomas according to the latest WHO definition. In the same classification, a subset of tumors with relatively distinct histopathological features was identified and defined as atypical adenomas designated to follow a more aggressive clinical course. This classification, although clinically useful, does not provide an accurate correlation between histopathological findings and the clinical behavior of these tumors, neither is it adequate to convey the precise features of 'aggressive' tumors. Thus, 'aggressive' pituitary adenomas need to be properly defined with clinical, radiological, histological and molecular markers in order to identify patients at increased risk of early recurrence or subsequent tumor progression. At present, no single marker or classification system of pituitary tumor aggressiveness exists, and clinically useful information in the literature is insufficient to guide diagnostic and therapeutic decisions. Treatment of patients with aggressive pituitary tu-
\end{abstract}

(c) 2015 S. Karger AG, Basel

0028-3835/15/1012-0087\$39.50/0 mors is challenging since conventional treatments often fail, necessitating multiple surgical procedures with additional radiotherapy. Although traditional chemotherapy applied in other neuroendocrine tumors has not been shown to be efficacious, newer agents, particularly temozolomide, have shown promising results and are currently used despite the lack of data from a randomized prospective trial. Molecular targeted therapies such as mTOR and epidermal growth factor inhibitors have also been applied and might prove to be useful in the management of these patients. In the present review, we provide information regarding the epidemiology and clinical, histopathological and molecular features of aggressive pituitary tumors using recent employed definitions. In addition, we review currently employed therapeutic means providing a therapeutic algorithm and highlight the need to identify more specific disease-related and prognostic markers and the necessity for central registration of these tumors.

(c) 2015 S. Karger AG, Basel

\section{Introduction}

Pituitary adenomas are relatively common tumors arising from adenohypophyseal cells and account for 10$15 \%$ of all intracranial neoplasms [1]. Their prevalence based on recent cross-sectional community-based studies is estimated at $80-90$ per $100,000[2,3]$. Pituitary adenomas are divided into microadenomas and macroad-

\section{KARGER 125}

E-Mail karger@karger.com

www.karger.com/nen
Assoc. Prof. Gregory Kaltsas, MD, FRCP

Endocrine Unit, Department of Pathophysiology

National University of Athens

Mikras Asias 75, GR-11527 Athens (Greece)

E-Mail gkaltsas@endo.gr 
enomas by an arbitrary cutoff size of $10 \mathrm{~mm}$, whereas when tumors exceed 30 or $40 \mathrm{~mm}$ in size, the term giant adenomas is used. Most of these tumors are noninvasive and benign in nature, and remain either within the sella or exhibit slow expansive growth displacing surrounding tissues. A significant number of pituitary tumors, 25$55 \%$ depending on the criteria used, can show signs of invasion of dura, bone and/or surrounding anatomical structures $[4,5]$. However, these so-called 'invasive' pituitary adenomas display benign behavior even in the presence of marked dural invasion and are not considered malignant by current definition. Truly malignant pituitary tumors (pituitary carcinomas) are only defined by the presence of cerebrospinal or systemic metastases and are exceedingly rare, with an incidence of $0.2 \%$ of symptomatic pituitary tumors $[1,6]$. The so-called 'aggressive' adenomas lie between benign adenomas and malignant pituitary carcinomas and display a rather distinct clinical behavior with marked/gross invasion of nearby anatomical structures and a tendency towards resistance to conventional treatments and early postoperative recurrence.

In 2004, the WHO published a classification system for pituitary tumors based upon immunohistochemistry distinguishing them according to the presence or absence of secretory products along with various other ultrastructural features (table 1) [7]. Apart from benign typical adenomas and pituitary carcinomas, this classification also identified atypical adenomas as tumors with 'atypical' morphological features suggestive of an 'aggressive behavior', substantiated further by the presence of invasive growth, high mitotic index, a Ki67 labelling index (LI) $>3 \%$ as well as extensive nuclear staining for $\mathrm{p} 53$. This was the first attempt to identify pituitary tumors that have the potential to exhibit a distinctive course compared to benign adenomas, characterized by extensive growth and potentially malignant transformation $[5,8]$. However, invasive growth included in the WHO criteria was not clearly defined and accounted for [9] since it is usually underestimated if no relevant information from imaging studies is considered [10]. Furthermore, this classification based on histopathological markers does not closely correlate with clinical behavior, as typical adenomas may occasionally exhibit early recurrence and resistance to therapy, whereas atypical adenomas are not always invasive, and they do not always exhibit recurrence. It is also acknowledged that atypical adenomas may share morphological and histological features with carcinomas, which are distinctively characterized by craniospinal or distant metastases, poorer prognosis and an overall fatal
Table 1. Classification of pituitary tumors according to the WHO [7]

PRL-secreting adenoma (lactotroph adenoma or prolactinoma)

Densely granulated

Sparsely granulated

$\mathrm{GH}$-secreting adenoma (somatotroph adenoma)

Monohormonal

Densely granulated

Sparsely granulated

Plurihormonal

Mixed GH-PRL

Mammosomatotroph

Acidophilic stem cell

ACTH-secreting adenoma (corticotroph adenoma)

Densely granulated

Sparsely granulated

Silent corticotroph subtype 1 and 2

TSH-secreting adenomas (thyrotroph adenoma)

Densely granulated

Sparsely granulated

FSH/LH adenoma (gonadotroph adenoma or nonfunctioning adenoma - NFPA)

Null-cell adenoma (oncocytoma)

Various

Silent subtype 3 tumor

Plurihormonal

outcome. Therefore, the validity of the term 'atypical adenoma' proposed by the 2004 WHO pituitary tumor classification system is now debatable, and tumors with a potential to follow an aggressive clinical course need to be properly identified, introducing a new classification system incorporating novel molecular and genetic biomarkers that have recently been evaluated [11].

\section{Definition of Aggressiveness}

In contrast to the term 'atypical adenomas' which was based on proliferative and histological markers, the term 'aggressive' pituitary tumors is not well-defined and is interpreted differently by individual clinicians. One aspect of aggressiveness is invasive expansion into surrounding anatomical structures. The terms 'aggressive' and 'invasive' are often interchangeably and synonymously used in the literature; however, this is not always the case and creates considerable confusion as microscopic dura and cavernous sinus invasion and suprasellar expansion are commonly encountered in apparently benign adenomas [12]. There is also great variation in the literature regarding the definition of invasiveness based on imaging features, his-
Chatzellis/Alexandraki/Androulakis/ Kaltsas 
Fig. 1. Hardy's classification of pituitary tumors (based on Hardy [148] and Kovacs and Horvath [149]). Upper panel shows the classification of sphenoid bone invasion (grade 0: intact with normal contour; grade I: intact with bulging floor; grade II: intact, with enlarged fossa; grade III: localized sellar destruction; grade IV: diffuse destruction). Only grade III and IV tumors are considered invasive. Lower panel depicts a classification of the suprasellar extension of an adenoma which may be symmetrical or asymmetrical [grade A: suprasellar cistern only; grade B: recess of the third ventricle; grade $\mathrm{C}$ : whole anterior third ventricle; grade D: intracranial extradural; grade $\mathrm{E}$ : extracranial extradural (cavernous sinus)].

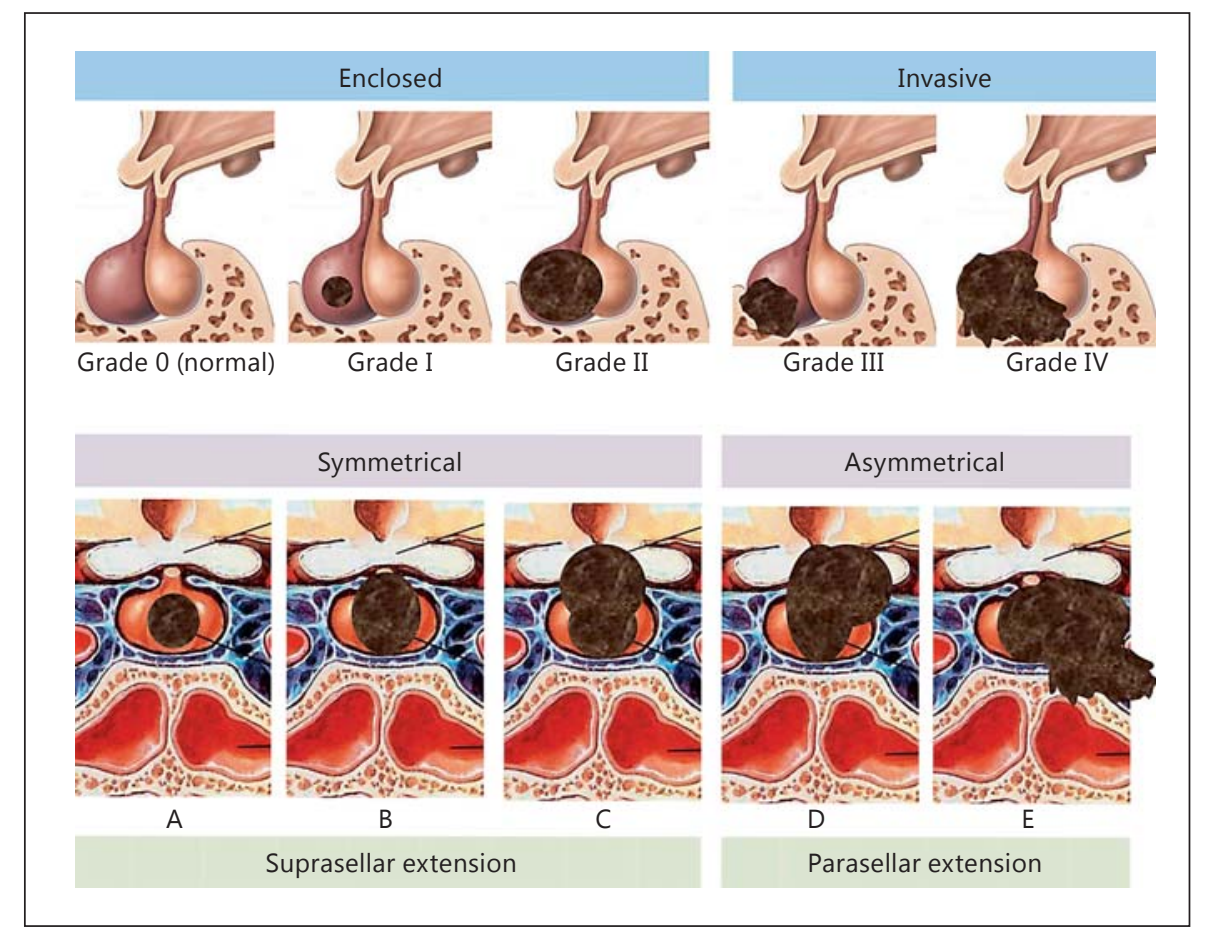

tological proof of sphenoid sinus mucosal invasion and/ or intraoperative findings [13]. Furthermore, the precise anatomical structure infiltrated is of importance since invasion of the clivus or sphenoid bone, as opposed to cavernous sinus invasion, is a more indicative feature of aggressive behavior [14]. In Hardy's classification for example, only grade III (focal bone erosion) and grade IV (extensive bone erosion including skull base) tumors are considered invasive (fig. 1) [15]. Moreover, regarding parasellar invasion of the cavernous sinuses according to Knosp's classification, only grade III and IV adenomas are considered truly invasive (fig. 2) [16].

Another feature of aggressiveness characterizing the behavior of such tumors is recurrence. Patients with apparently cured benign typical adenomas may develop recurrence of their tumors after 5-10 years; however, early recurrence, 6-12 months postoperatively, and the rapidity of tumor growth are more in favor of a tumor with a rather 'aggressive' behavior, although there is still no definite time to tumor progression cutoff to distinguish these tumors from truly benign adenomas. Additionally, patients with 'aggressive' tumors usually exhibit resistance to conventional therapies, although early or late resistance to treatment may also occasionally occur in benign tumors, reflecting specific tumor receptor heterogeneity, tachyphylaxis and/or other unknown factors affecting drug efficacy.

Aggressive Pituitary Tumors
Aggressive pituitary tumors are thought to have a greater chance of giving rise to pituitary carcinomas with cerebrospinal or systemic metastases. Pituitary carcinomas develop with equal frequency in both sexes at a mean age of 44 years, with a latency period of 7 years after the diagnosis of a pituitary tumor depending on tumor subtype [1]. Although de novo development of a malignant pituitary tumor cannot be excluded, in most case series pituitary carcinomas evolve from macroadenomas that exhibit invasive and proliferative features [10, 17, 18]. This supports the view that pituitary carcinomas mainly arise from the transformation of initially 'benign' adenomas that accumulate genetic aberrations over time exhibiting an 'aggressive' behavior and eventually metastasizing [1]. However, as not all aggressive tumors transform into carcinomas, it is important to develop tools to identify the subset of tumors at higher risk and apply close clinical and radiological surveillance along with all available treatments early in the course of the disease in an attempt to minimize their morbidity.

\section{Epidemiology}

Based on the WHO definition of atypical adenomas, several retrospective cross-sectional studies have reported on the prevalence of such tumors (table 2). Saeger et 


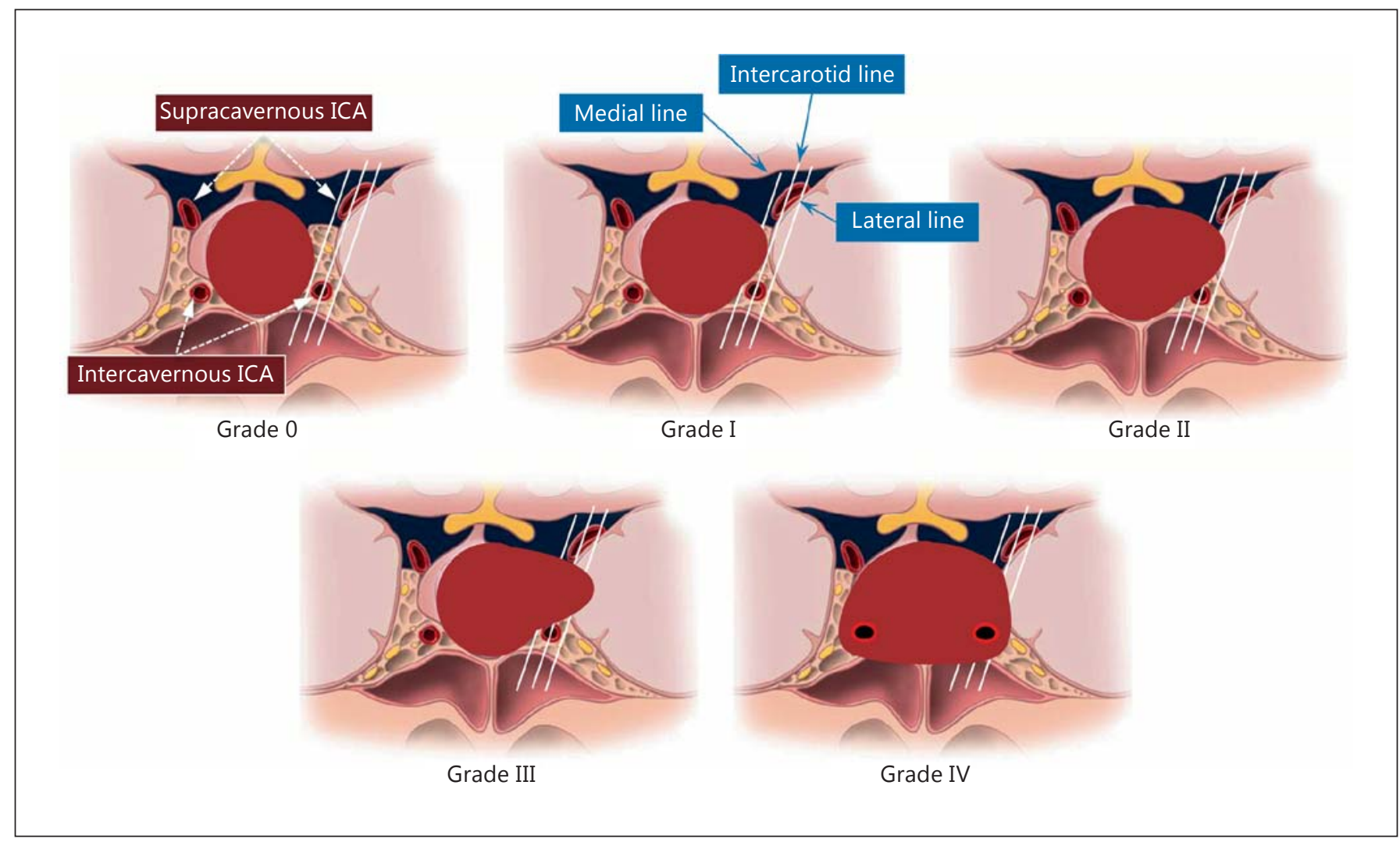

Fig. 2. Knosp's classification of cavernous sinus invasion. Grade 0: the adenoma does not pass the tangent of the medial aspects of the internal carotid artery (ICA); grade I: the medial tangent is passed, but the extension does not go beyond the intercarotid line, which is the line drawn between the cross-sectional centers of the intraand supracavernous ICA. Grade II is characterized by the tumor extending beyond the intercarotid line, but not beyond or tangent to the lateral aspects of the intra- and supracavernous ICA. Grade III is characterized by the tumor extending laterally to the lateral tangent of the intra- and supracavernous ICA. Grade IV is characterized by total encasement of the intracavernous carotid artery (based on Knosp et al. [16]).

Table 2. Published series of atypical pituitary adenomas

\begin{tabular}{|c|c|c|c|c|c|c|c|}
\hline Study & $\begin{array}{l}\text { Total } \\
\text { adenomas }\end{array}$ & $\begin{array}{l}\text { Atypical adenomas } \\
\text { (prevalence) }\end{array}$ & NFPA & PRL & $\mathrm{GH}$ & ACTH & Recurrence \\
\hline Scheithauer et al. [129] & 78 & $6(14.7 \%)$ & n.a. & n.a. & n.a. & n.a. & $5 / 6$ \\
\hline Saeger et al. [19] & 451 & $12(2.7 \%)$ & 5 & 1 & 3 & 3 & n.a. \\
\hline Zada et al. [20] & 121 & $18(14.8 \%)$ & 9 & 2 & 5 & 2 & $4 / 18$ \\
\hline Yildirim et al. [21] & 146 & $13(8.9 \%)$ & 9 & 3 & 1 & 1 & $5 / 13$ \\
\hline Total & 796 & 49 (6.2\%) & 23 & 6 & 9 & 6 & $14 / 37$ \\
\hline
\end{tabular}

n.a. $=$ Not available.

al. [19] reported 12 atypical cases out of a total of 451 pituitary adenomas $(2.7 \%)$ in the German Pituitary Tumour Registry. Scheithauer et al. [6] reported 6 atypical cases out of 78 total pituitary adenomas, an incidence of $14.7 \%$ similar to the one reported by Zada et al. [20]. In a more recent single-center study, $8.9 \%$ (13 out of 146) of pituitary adenomas were atypical, and $38.4 \%$ of them developed recurrence [21]. Apart from these reports, there are no further studies describing similar epidemiological data on 'aggressive' pituitary tumors. This is mainly at- 
tributed to the lack of a standardized definition of an 'aggressive' tumor based not only on histological or proliferative markers, but also on the clinical course and behavior.

\section{Pathogenesis}

At the molecular level, there is evidence that pituitary tumors accumulate abnormalities in molecular pathways over time that contribute to their progression from 'benign' adenomas to aggressive recurrent pituitary tumors and in exceptional cases to pituitary carcinomas. Genetic or epigenetic abnormalities, paracrine growth factor disruptions and altered intrapituitary microenvironment may be associated with pituitary-selective oncoprotein activation or tumor suppressor gene inactivation, leading to sustained cell proliferation. However, the primary initiating cause of these events remains elusive, whereas current knowledge on pathogenesis of pituitary tumors has extensively been reviewed elsewhere and is beyond the scope of the current review [22, 23].

\section{Histological and Molecular Biomarkers of Pituitary Tumor Aggressiveness}

An accurate histopathological description and subtype recognition of pituitary adenomas based on the latest WHO classification is an independent predictor of aggressive behavior in the majority of pituitary adenomas [24]. Crooke's cell adenomas, sparsely granulated somatotroph adenomas, densely granulated lactotroph adenomas, acidophil stem cell adenomas, thyrotroph adenomas, sparsely granulated corticotroph adenomas, silent subtype 3 adenomas and null cell adenomas (table 1) are all associated with aggressive clinical behavior [25]. Adenoma type in combination with some specific clinical features may also indicate an aggressive phenotype. This applies to large prolactinomas in male patients [26], dopamine agonist-resistant prolactinomas [27], plurihormonal and gonadotroph adenomas (nonfunctioning) that at the time of the diagnosis are usually large and display invasiveness to surrounding tissues.

Apart from the histological subtype, proliferation markers may also reflect the aggressive potential of pituitary adenomas by determining the rate of multiplication of neoplastic pituitary cells. The number of mitoses has only limited value as pituitary adenomas, even aggressive ones, have a low proliferation rate with occasional mito-

Aggressive Pituitary Tumors ses [28], whereas delayed fixation, intraobserver and interobserver variations and apoptotic features mimicking mitoses affect the diagnostic accuracy [29]. In contrast, the immunohistochemical (IHC) detection of the Ki67 antigen using the MIB-1 antibody appears to be superior to mitotic count in assessing tumor proliferation activity as it is expressed during all non- $\mathrm{G}_{0}$ phases of the cell cycle, except for the early $G_{1}$ phase, and is more reliably determined. The vast majority of pituitary adenomas have Ki67 LI values between 1 and 2\%, whereas values $>3 \%$ are uncommon. Thapar et al. [5] reported that a 3\% Ki67 LI cutoff value is associated with $72.7 \%$ sensitivity and $97.3 \%$ specificity and a positive and negative predictive value of 96 and 80\%, respectively, in distinguishing noninvasive from invasive pituitary adenomas. It has also been suggested that a Ki67 LI >10\% should always raise suspicion regarding the malignant potential of the tumor [30]. In the recent WHO classification [7], Ki67 LI was regarded as a major predictive indicator for distinguishing benign from atypical adenomas; however, the ability of Ki67 LI to predict tumor invasiveness remains controversial as discrepant results have been reported [13].

Another histopathological marker related to aggressive pituitary tumor behavior is p53 IHC expression, a tumor suppressor protein encoded by the TP53 gene [31]. In normal cells, p53 is present at very low levels which are undetectable by IHC, whereas mutant forms have a longer halflife, are more stable, accumulate in the nucleus and are detected by IHC [31]. p53 immunoreactivity appears to correlate with tumor invasiveness, as it is present in 15\% of invasive adenomas and all pituitary carcinomas, but is absent in noninvasive adenomas [8]; however, this finding has not been reproduced in all studies [32]. In the latest WHO definition, p53 IHC expression was included along with Ki67 LI as a criterion of atypical pituitary adenomas; however, due to discrepant results, its predictive value as an independent factor has been questioned. Moreover, there are some limitations concerning the validity of its quantification $[8,33]$ as positive IHC is defined by the presence of $>10$ strongly stained nuclei per $10 \mathrm{HPFs}$.

From all these studies, it is evident that no single morphological or histological feature can serve as a reliable predictor of pituitary tumor behavior. Therefore, efforts have been made to combine morphological, clinical and radiological features to provide a more comprehensive and conclusive tool to differentiate benign (typical) from aggressive and potentially malignant pituitary tumors. One such classification that combines radiological and histological findings based on invasiveness (histological and/or radiological signs of cavernous sinus or sphenoid 
Table 3. Biomarkers of aggressiveness

\begin{tabular}{ll}
\hline Histological & Novel biological markers \\
\hline Histological subtype & Genomic imbalance (11q allelic loss) \\
Crooke's cell adenomas & DNA aneuploidy \\
Sparsely granulated somatotroph adenomas & MYO5A \\
Densely granulated lactotroph adenomas & Germline mutations associated with MEN1, MEN4, \\
Acidophil stem cell adenomas & Carney complex, FIPA and SDH \\
Thyrotroph adenomas & Micro-RNAs \\
Sparsely granulated corticotroph adenomas & p27 \\
Silent subtype 3 adenomas & Senescence markers (p16, p21, $\beta$-galactosidase) \\
Null cell adenomas & PTTG \\
Ki67 LI & HEPN-1 \\
p53 & Growth factors (EGF, VEGF) and their receptors (EGFR, VEGFR) \\
Multimodal classification system & FGF-2 and ptd-FGFR4 \\
(invasion, proliferation markers) & MMPs \\
& NCAM \\
& Galectin-3 \\
\hline
\end{tabular}

FIPA = Familial isolated pituitary adenoma; $\mathrm{SDH}=$ succinate dehydrogenase NCAM = neural cell adhesion molecule.

sinus invasion) and proliferative markers ( 2 of the following 3 criteria: Ki67 index $\geq 3 \%$; $>2$ mitoses per $10 \mathrm{HPFs}$; or p53 immunopositivity) has recently been proposed by Trouillas et al. [10]. On the basis of these criteria, pituitary tumors are subdivided into 3 grades: grade 1 , noninvasive ( $1 \mathrm{a}$, noninvasive and nonproliferative; $1 \mathrm{~b}$, noninvasive and proliferative); grade 2 , invasive ( $2 \mathrm{a}$, invasive and nonproliferative; $2 \mathrm{~b}$, invasive and proliferative), and grade 3 , metastatic (carcinomas). Applying these criteria retrospectively in 410 patients with pituitary adenomas, patients classified as grade $2 \mathrm{~b}$ exhibited a 25 -fold and 12 fold higher probability of tumor persistence or recurrence, respectively, after 8 years of follow-up, compared to patients with grade 1a tumors [10]. From the same study, it became apparent that imaging findings of cavernous or sphenoid sinus invasion were more sensitive in identifying invasive tumors compared to histology (175/410, $42.7 \%$ vs. $16 / 410,9 \%$, respectively). During a follow-up period of 8 years, 4 adrenocorticotropic hormone (ACTH)- and 4 prolactin (PRL)-producing pituitary carcinomas developed from previously nonmetastatic tumors ( 6 grade $2 \mathrm{~b}$ adenomas, 1 grade $2 \mathrm{a}$ and 1 grade $1 \mathrm{~b}$ ). This proposed classification system, although requiring validation from further prospective studies with longer follow-up, has shown that a multimodal approach, considering morphological, molecular, clinical and radiological features, seems to be the most efficient way to accurately classify pituitary tumors according to their prognostic potential [34].

\section{Evolving Biomarkers of Pituitary Tumor Aggressiveness}

Following the extensive research and knowledge on pituitary tumorigenesis acquired over the last decades, several novel biomarkers have been studied in order to assess their validity as predictive markers of pituitary tumor aggressive behavior. These include chromosomal alterations and microRNAs (miRNAs), proliferation markers, oncogenes, tumor suppressor genes, growth factors and their receptors, and factors related to angiogenesis or cell adhesion (table 3). However, no single biomarker has been found to independently predict aggressive behavior in pituitary neoplasms.

Genomic imbalance has been reported to occur frequently in pituitary tumors [35-37]. The most frequent and extensive alteration observed in aggressive tumors corresponds to the allelic loss of the short arm of chromosome $11(11 \mathrm{p})$, particularly in PRL-producing tumors [38]. Pituitary tumors show a wide range of DNA aneuploidy through image analysis cytometry and flow cytometry, and some authors have reported a positive correlation of aneuploidy with the mitotic index and tumor recurrence [39], although this view is not widely accepted [28].

Differential gene expression profiling using microarray analysis revealed a genetic signature of invasive tumors characterized by overexpression of 4 genes (IGFBP 5 , MYO5A, FLT3 and NFE2L1) compared to noninvasive 
adenomas. Only the protein product of MYO5A was more frequently detected with IHC in invasive adenomas, constituting a candidate marker of tumor aggressiveness [40]. MYO5A is a member of the myosin family, and its role in tumor cell invasion and metastasis has recently been described [41].

Germline mutations that cause familial predisposition to pituitary tumors, including multiple endocrine neoplasia (MEN) type 1 (MEN1), MEN4, Carney complex and familial isolated pituitary adenoma, as well as mutations in genes encoding succinate dehydrogenase (SDHB, SDHC and SDHD) [42], have also been linked with a tendency to present with a more aggressive clinical course than sporadic adenomas [43-45].

Several studies have implicated the aberrant expression of miRNAs, small noncoding RNAs that regulate gene expression at the posttranscriptional level, as predictive markers in aggressive pituitary tumors [46]. Lower miR-141 expression has been shown to correlate with postoperative remission in patients with corticotroph adenomas, while downregulation of miR-15a and miR-16-1 has been linked to tumor size in growth hormone $(\mathrm{GH})$ and PRL-producing adenomas [47, 48].

Downregulation of $\mathrm{p} 27^{\mathrm{Kip} 1}$, an enzyme inhibitor encoded by the CDKN1B gene, has also been linked with invasive and recurrent adenomas and pituitary carcinomas. The encoded protein binds to and prevents the activation of cyclin E-CDK2 [49] and is highly expressed in nontumorous adenohypophyseal cells and adenomas with a low proliferative rate [50], whereas its expression is much lower in invasive adenomas and pituitary carcinomas [51].

Recent studies on oncogene-induced senescence have highlighted the protective role of tumor suppressor genes p16 and p21 in restraining tumor growth and the malignant transformation of pituitary adenomas $[52,53]$. Senescent cells show altered cell morphology, including increased lysosomal breakage, causing the lysosomal enzyme $\beta$-galactosidase to enter into the cytoplasm [54]. In a recent study, it has been suggested that the senescence pathway, as assessed by $\beta$-galactosidase IHC, is more activated in GH-secreting and nonfunctioning pituitary adenomas (NFPAs) [55]. Moreover, a negative correlation was found between Ki67 LI and cytoplasmic staining for both p16 and p21. There are also data on methylationassociated gene silencing involving p16 and other genes such as $\mathrm{pRb}$ and DAPK in pituitary tumors which would suggest that methylation profiling might provide a useful biomarker of aggressiveness $[56,57]$.

Aggressive Pituitary Tumors
A further gene that has been extensively studied and shown to correlate with invasion in several tumor types is the pituitary tumor-transforming gene (PTTG), a member of the securin family, which regulates sister chromatid separation during mitosis [58]. Loss of the PTTG function suppresses cell proliferation, diminishing the development of pituitary tumors in retinoblastoma proteindeficient animals [59], whereas increased PTTG expression is expected to lead to tumorigenesis. Concerning human pituitary tumors, PTTG expression was higher in hormone-secreting invasive pituitary adenomas compared to noninvasive ones [60], whereas a PTTG/Ki67 score $>2.9$ correlated with a clinically aggressive behavior in pituitary adenomas [61].

A recently published study [62] has evaluated the effect that HEPN1 (hepatocellular carcinoma, downregulated 1) gene silencing exerts on the biological behavior of pituitary somatotroph adenomas, presenting a novel candidate tumor suppressor gene. Reduced expression of the HEPN1 gene was more frequently found in invasive human pituitary tumors, whereas loss of HEPN1 function in pituitary adenoma cell lines (GH3 and GT1.1) promoted proliferation and invasiveness of pituitary adenoma cells and inhibited apoptosis.

Growth factors such as epidermal growth factors (EGFs), vascular endothelial growth factors (VEGFs), fibroblast growth factors (FGFs) and their receptors (EGFR, VEGFR and FGFR, respectively) have also been found to be involved in pituitary tumor aggressiveness $[63,64]$. FGF-2 is overexpressed in pituitary tumor cells with higher levels in more aggressive tumors [65]. A truncated form of the FGF receptor-4 (FGFR4 or ptd-FGFR4) has been shown to induce pituitary tumor invasion in vitro and in in vivo animal models. This constitutively activated protein is found in approximately $60 \%$ of tumors (mostly GH-, ACTH- and FSH-/LH-producing adenomas) and correlates with Ki67 LI [66]. The ability of pituitary tumors to invade surrounding tissues depends on the presence of matrix metalloproteinases (MMPs) that break down membranes and connective tissue. Expression of MMP9 and MMP2 was found to correlate with the degree of invasion, adenoma phenotype and a high radiological grade of invasiveness in some but not all studies [32, 67-69]. Expression of the polysialylated form of neural cell adhesion molecule has also been associated with tumor aggressiveness [70].

A further recent study has elucidated the role of galectin-3, a $\beta$-ganglioside-binding lectin involved in cell adhesion, growth, differentiation and apoptosis encoded by the LGALS3 gene, as a possible predictive marker of ag-

Neuroendocrinology 2015;101:87-104 
gressive tumor behavior in $92 \mathrm{ACTH}$ - and PRL-secreting adenomas [71]. LGALS3 IHC was found in more than $30 \%$ of neoplastic cells and along with LGALS3 mRNA positivity they were more important markers than Ki67 LI, for predicting progression or recurrence. However, the reliability of genomic and molecular markers remains to be assessed in large prospective studies, alone or as part of multimodal prognostic models.

\section{Diagnosis}

\section{Clinical Features}

The initial clinical features of aggressive pituitary adenomas do not differ from nonaggressive typical adenomas and are mainly attributed to pressure effects to surrounding tissues and/or to the effects of excessive hormonal secretion. Being by definition more invasive than their typical and benign counterparts, symptoms such as visual impairment, presenting either as visual field loss or a reduction in visual acuity and/or cranial nerve palsies, usually dominate the clinical picture. In several cases, the presence of relatively unusual symptoms/signs not commonly encountered in benign pituitary tumors, such as hearing loss, ataxia, and/or motor impairment, cerebrospinal fluid leak or hydrocephalus, may point to the presence of an aggressive/invasive tumor [1, 72]. However, the most common clinical presentation of aggressive pituitary tumors is early recurrence after initial pituitary surgery, and rapid local growth and tumor extension. Most aggressive pituitary tumors were initially considered to be hormonally active, which is in line with the significantly higher Ki67 LI found in secreting compared to nonsecreting adenomas [73, 74]. However, a critical analysis of the well-documented published series of atypical adenomas (table 2) has revealed that approximately half of these tumors are nonfunctioning, whereas atypical $\mathrm{GH}$-secreting adenomas appear more frequent than atypical ACTH or PRL tumors. Symptoms related to hormonal hypersecretion usually do not differ from those encountered in patients with benign adenomas, and there are no hormonal level cutoffs that differentiate aggressive from benign or malignant macroadenomas, although higher pro-opiomelanocortin levels may be associated with a more aggressive course in patients with Cushing's disease [75]. Very high levels of PRL, ACTH, and/or GH despite apparent surgical clearance of the tumor should raise suspicion for the presence of more aggressive or potentially malignant pituitary tumors. Similarly, worsening of the secretory status due to partial or complete sec- ondary resistance to dopamine agonists and/or somatostatin analogs (SSAs) in patients with PRL- and $\mathrm{GH}$-secreting adenomas is a further feature suggestive of aggressive tumors [72].

\section{Imaging}

Current imaging diagnostic modalities, mainly magnetic resonance imaging, exert high sensitivity in detecting aggressive pituitary tumors which in their great majority are macroadenomas, but currently there are no reliable features distinguishing aggressive from apparently 'benign' adenomas. In the series of atypical adenomas reported by Zada et al. [20], 17 out of 18 atypical adenomas (94\%) were macroadenomas, and radiological invasion was evident in $15 / 18(83 \%)$ compared to $45 \%$ of typical adenomas $(\mathrm{p}=0.004)$. Ten lesions $(56 \%)$ showed infrasellar invasion with clival or sellar floor erosion, 9 (50\%) showed suprasellar invasion and $6(33 \%)$ invaded at least 1 cavernous sinus; in 5 patients (28\%), invasion of all 3 regions was noted.

Application of Knosp's and Hardy's radiological classification systems (fig. 1 and 2, respectively) could help evaluate the extent and type of invasion of these tumors, although there is no strong evidence relating each grade with the clinical course. However, the radiological proof of invasiveness in combination with proliferation markers and adenoma classification may help predict the clinical behavior [10].

\section{Treatment}

In general, aggressive pituitary tumors are by definition notoriously difficult to manage due to their size, invasiveness, rapid growth and high frequency of recurrence. Treatment options include surgery, external radiotherapy, medical treatment and peptide receptor radionuclide therapy (PRRT). Since clear-cut definition and reliable prognostic markers are lacking, aggressive pituitary tumors are difficult to be identified at initial presentation, and therefore the primary therapeutic approach is no different compared to other pituitary tumors depending on the type of adenoma.

\section{Initial Treatment after Diagnosis}

Apart from patients with prolactinomas, all other patients with pituitary tumors should be offered curative or debulking transphenoidal surgery unless comorbidities are present that increase the perioperative risk. Prolactinomas are initially treated with dopamine agonists, main-
Chatzellis/Alexandraki/Androulakis/ Kaltsas 
ly cabergoline, which is efficient in controlling tumor growth and PRL levels in most cases [76]. Resistance to dopamine agonists presenting as escalating PRL levels and/or tumor growth can be an early indicator of aggressiveness, but this may not always be the case, as some 'benign' prolactinomas may show resistance due to polymorphisms in the dopamine receptor [77]. For prolactinomas refractory to medical treatment, maximizing cabergoline dosage beyond conventional doses has been proposed, as long as adverse effects are tolerable [76]. In patients with invasive $\mathrm{GH}$-secreting macroadenomas and giant adenomas, preoperative use of long-acting SSAs may achieve preoperative tumor shrinkage, although studies evaluating improvement of surgical outcomes have produced controversial results [78-80]. Patients failing to be cured surgically or recurring after initial cure are treated with the long-acting SSAs lanreotide and octreotide, either alone or in combination with the GH receptor antagonist pegvisomant; resistance to these agents heralds a more aggressive course. Sparsely granulated GH-producing tumors have also been reported to be resistant to medical treatment with SSAs compared to the densely granulated type [81].

Aggressive ACTH adenomas causing Cushing's syndrome are usually invasive macroadenomas, and surgery achieves low remission rates ranging between 22 and $65 \%[82,83]$. Repeated debulking surgeries can be applied along with medical agents including inhibitors of steroidogenesis, dopamine agonists, glucocorticoid receptor blockers, the novel SSA pasireotide [84] or drugs currently under investigation such as LCI699 [85]. Bilateral adrenalectomy is also effective in controlling cortisol excess; however, removal of cortisol-mediated negative feedback on the pituitary tumor may serve as a growth stimulus to corticotroph tumors, especially aggressive ones, increasing the risk of developing Nelson's syndrome [86].

Gonadotropin-producing pituitary adenomas, categorized by the WHO as NFPA, are often discovered late as invasive macroadenomas, and medical treatment is ineffective and currently not indicated. Very few data exist for the rare TSH-secreting tumors (TSHomas), most of which are diagnosed as macroadenomas with frequent suprasellar extension or sphenoidal sinus invasion [87]. In addition, these tumors may frequently be aggressive, locally invasive, involving the cavernous sinus, internal carotid artery or other structures, may present marked fibrosis, possibly related to a high expression of FGF-2 [88] or dense calcification [89], thus rendering complete resection of the tumor either impractical or dangerous.
Treatment with SSAs is highly effective, controlling TSH secretion in most and inducing tumor shrinkage in $40 \%$ of patients [90], while resistance and escape phenomenon have been described in a minority of cases [91].

\section{Surgical Therapy}

All medical treatments in patients harboring aggressive pituitary tumors are often ineffective in controlling hormonal hypersecretion and/or tumor growth. Hence, resurgery appears a feasible treatment option for aggressive and/or recurrent tumors, although remission rates after repeated transsphenoidal surgery are much lower [92-94]. In cases where tumors extend significantly into the suprasellar region, the transcranial approach may still be advantageous but the transsphenoidal or endoscopic surgical approaches are also valid and can be used depending on the surgeon's experience [14]. Near-total surgical resection with no apparent remnant in imaging postoperatively can rarely be achieved as aggressive pituitary tumors tend to be infiltrative and recur over a relatively short time [95]. Repeated pituitary tumor debulking surgeries can be performed to remove further emerging tumor tissue albeit with less success and increasing rate of complications such as worsened visual field, optic nerve palsy, meningitis, anterior pituitary deficiencies and diabetes insipidus [96], and can be combined with other therapeutic modalities such as systemic and/or radiological therapies to achieve tumor control.

\section{Radiation Therapy}

Radiation therapy (RT) for aggressive pituitary tumors that recur, continue to grow or are not biochemical controlled despite medical and/or surgical therapy is a further therapeutic option. Conventional external RT has been used in adjuvant settings to prevent tumor regrowth in large or partially removed pituitary tumors and for local control of expanding tumors, some of which were later proven to be aggressive pituitary tumors. RT efficacy ranges in several studies from 67 to $100 \%$ depending on the selection of cases [97]. Conventional radiotherapy has been shown to reduce recurrence of NFPA remnants, particularly if administered immediately during the postoperative period [98], but its efficacy is often limited in aggressive tumors. While a tumoristatic effect is the most common outcome regarding tumor growth control, in rare instances tumor shrinkage has been reported [99]. Stereotactic radiosurgery with delivery of high-dose radiation in a single visit or fractionated RT (smaller fractions of radiation given over a period of 4-6 weeks) can also be applied if the tumor is adjacent to radiation-sen- 
sitive normal tissues. Techniques such as Gamma Knife surgery, linear accelerator or CyberKnife can provide more precise targeting of the adenoma, offering better control of the dose of radiation received by adjacent structures, such as the pituitary stalk, pituitary gland, optic chiasm and cranial nerves in the cavernous sinus. Retrospective series with new radiosurgery methods published to date have shown similar results as conventional RT [100] with a tendency to achieve their effect slightly faster and with less frequent side effects, mainly pituitary deficiency [101]. In contrast to repeated surgical debulking, the amount of radiation treatment that can be administered is limited by the risk of optic neuropathy, necrosis in the temporal lobe and other brain areas and the rare possibility of developing a secondary brain tumor. There has also been concern regarding the possible role of radiotherapy in the transformation or progression of pituitary adenomas to carcinomas following reports of sarcomatous changes induced by RT on pituitary adenomas [102]. However, this is unlikely to be a general process in view of the large number of irradiated pituitary tumors and the small number of pituitary carcinomas [103]. Reirradiation using stereotactic linear accelerator or Gamma Knife radiosurgery can be considered as a salvage/palliative choice in selected previously irradiated patients to achieve local growth control with acceptable complication rates, given the lack of options that may be available otherwise; however, this approach did not control hormonal hypersecretion in one study [104]. Use of Gamma Knife surgery in patients who had previously undergone conventional RT led to an accelerated fall in GH excess and stabilization of NFPAs in the majority of cases [105], while no significant side effects were observed in a median follow-up of 36 months, except for a $43 \%$ incidence of new pituitary failure.

\section{Peptide Receptor Radionuclide Therapy}

PRRT has recently been proposed as a potential treatment option for aggressive pituitary adenomas based on the avid uptake of normal pituitary and adenoma tissue on positron emission tomography with gallium-labeled octreotide $\left({ }^{68} \mathrm{Ga}\right.$-DOTATATE PET/CT). The theoretical rationale relies on the delivery of a toxic dose of radiation to specific neoplastic cells expressing somatostatin receptors and is achieved using radiolabeled SSAs with agents such as ${ }^{90}$ Yttrium or ${ }^{177}$ Lutetium. PRRT has been used with great success in neuroendocrine neoplasms, particularly gastroenteropancreatic [106]. Although experience with PRRT in pituitary tumors is limited, a significant tumor shrinkage and clinical improvement following ad- ministration of a course of ${ }^{111}$ Indium-DTPA-octreotide in a patient with a recurrent giant prolactinoma resistant to conventional treatment have been described [107]. Symptomatic improvement and long-term control (8 years) were also reported in a patient with an atypical NFPA treated with ${ }^{177} \mathrm{Lu}$-DOTATOC [108], whereas in a small case series of 3 patients treated with ${ }^{177} \mathrm{Lu}$-DOTATATE, only 1 patient obtained a clinically useful response [109]. Larger prospective studies with dosimetric evaluation of absorbed dose and assessment of toxicity to surrounding normal brain tissue are required to establish the usefulness of this promising therapeutic modality.

\section{Chemotherapy}

Aggressive pituitary adenomas have relatively low proliferation indices and seem to retain certain aspects of well-differentiated tumors, thus responding poorly to standard chemotherapy regimens [110]. The same rule applies to pituitary carcinomas despite their relatively higher proliferation indices; however, due to the rarity of these tumors, no randomized prospective studies of systemic chemotherapy have been conducted. Different cytotoxic chemotherapy protocols including procarbazine-etoposide-lomustine (cyclo-hexyl-chloroethyl-nitrosourea or CCNU) [111] and lomustine-doxorubicin [112] have been used in individuals with aggressive pituitary tumors, achieving mostly transient tumor growth and hormonal responses. In a small series of 7 patients, of whom 3 had aggressive pituitary tumors and 4 carcinomas, combination therapy with lomustine and 5-fluorouracil showed an overall poor response rate in terms of tumor shrinkage, although temporary clinical responses were noticed in some patients [110]. Furthermore, observational data suggest that prolonged survival in some patients with pituitary carcinomas is associated with chemotherapy received prior to the appearance of distant metastases. Therefore, early use of chemotherapy may be of value in some patients with recurrent highly aggressive tumors as long as these patients can be readily selected based on markers that are currently missing from clinical practice [1].

\section{Temozolomide}

Since 2006, temozolomide (TMZ), originally approved for use in refractory glioblastoma multiforme, has been used to successfully treat pituitary carcinomas and aggressive pituitary adenomas (table 4). TMZ is an orally administered second-generation alkylating agent, an imadozotetrazine derivative that is rapidly converted at physiological $\mathrm{pH}$ to methyl-triazeno-imidazole-carbox-
Chatzellis/Alexandraki/Androulakis/ Kaltsas 
Table 4. Reported patients with aggressive pituitary tumors and carcinomas treated with TMZ

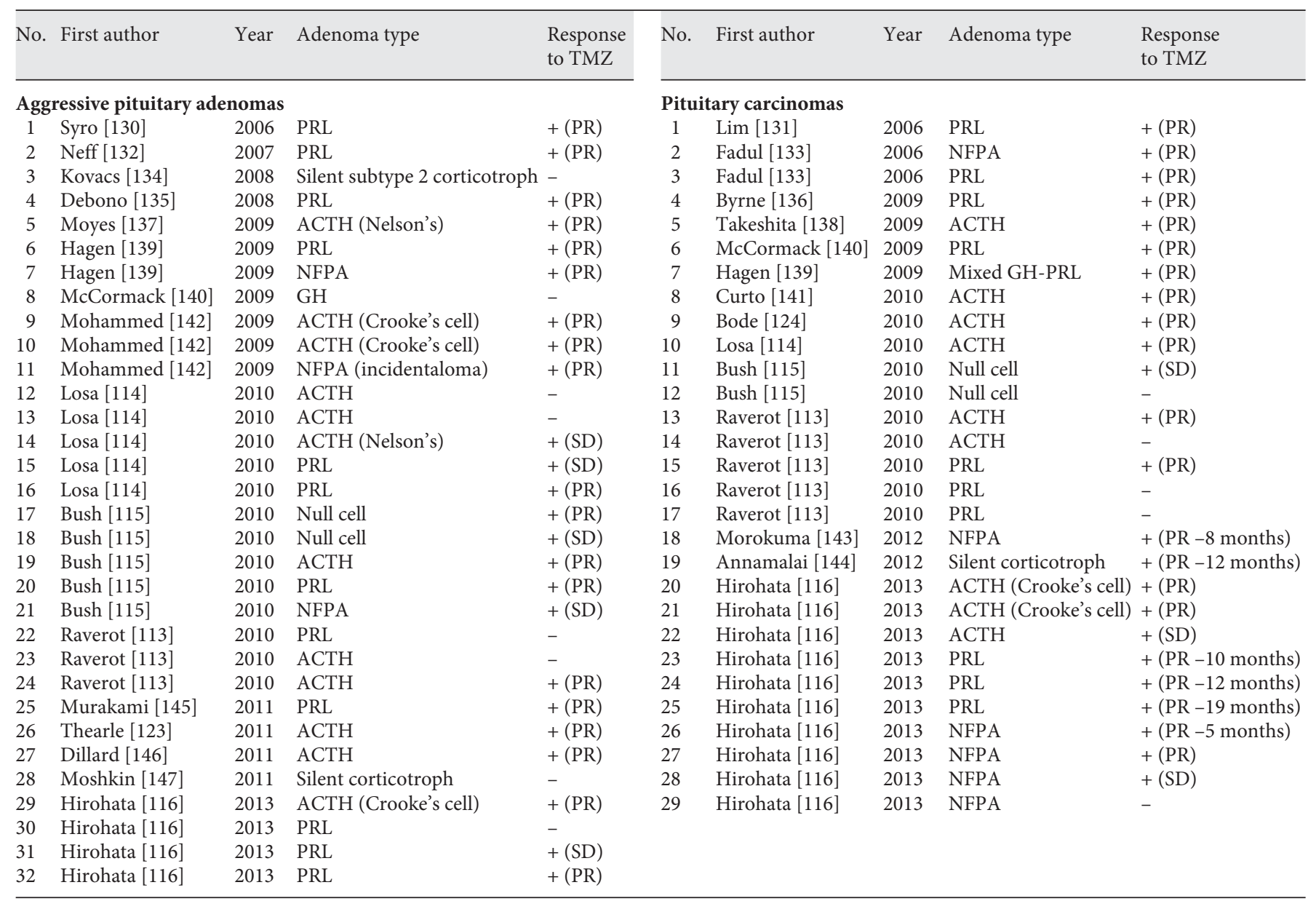

Total aggressive pituitary adenomas: PRL 12; ACTH 12; GH 1; NFPA 3; others (null cell, silent) 4; PR: 19 (59.4\%); SD: 5 (15.6\%); PD: 8 (25\%). Total pituitary carcinomas: PRL 10; ACTH 9; GH 0; NFPA 6; others (null cell, mixed) 4; PR: 21 (72.4\%); SD: 3 (10.3\%); PD: 5 (17.3\%). + = Favorable response including disease stabilization (SD) and partial responses (PR); - = tumor progression (PD).

amide, which is the active drug. It exerts its action by attaching a methyl group to the $\mathrm{O}^{6}$ position of guanine bases causing mispair with thymine bases, DNA damage, proliferation arrest and cell death (apoptosis). $\mathrm{O}^{6}$-methylguanine-DNA methyltransferase (MGMT) is a DNA repair enzyme that counteracts the effects of TMZ by removing alkylating adducts from DNA. TMZ can readily cross the blood-brain barrier, and its action is not cell cycle specific, thus inhibiting all stages of tumor cell growth, even in slow-growing tumors, such as pituitary tumors.

To date, 32 cases of aggressive pituitary tumors and 29 cases of pituitary carcinomas have been treated with TMZ in the literature (table 4). The overall clinical and radiological response rate was initially reported to be approximately $69 \%$ in carcinomas and 60\% in aggressive adeno- mas [96]. However, these response rates were based on published case reports that were successfully treated introducing a positive reporting bias. Combined data from 4 studies of small cohorts [113-116] reveal a mean tumoral response (partial response) in 55.5\% (10/18) of patients with carcinomas and $41 \%(7 / 17)$ with aggressive adenomas. If stabilization of the tumor (stable disease) is also considered as a favorable outcome, TMZ efficacy rises up to $72 \%(13 / 18)$ for carcinomas and $70.5 \%(12 / 17)$ for aggressive adenomas (table 4). Nevertheless, responses were frequently short lasting, and subsequent progression developed following an initial response to treatment. Some authors have also reported changes in histopathological and morphological features of tumors after TMZ treatment based on findings from reoperated patients. Tumor softening and friability were noticed, facilitating 
easier resection at reoperation, while TMZ-treated tumors exhibited fewer mitoses, lower Ki67 LI, hemorrhage, necrosis, focal fibrosis and absent MGMT in IHC $[117,118]$.

The DNA repair enzyme MGMT reverses the methylation caused by TMZ, being the major mechanism of resistance to TMZ treatment. A significant inverse correlation was found between IHC MGMT expression and response to TMZ; however, the absence of MGMT expression was not always predictive of tumor response $[113,115]$. On the contrary, studies examining MGMT promoter methylation in pituitary tumors confirmed its poor prognostic value since methylated MGMT promoter was found only in $60 \%$ of TMZ-sensitive tumors and $50 \%$ of TMZ-resistant tumors $[96,119]$. It appears that MGMT IHC but not MGMT promoter methylation status can be used to predict response to treatment in pituitary tumors. A clinically meaningful suggestion has been made by Raverot et al. [113] who have shown that 3 cycles of TMZ identify treatment-responsive patients, whereas after 3 cycles nonresponders do not benefit from additional cycles. Furthermore, recent studies have shown that MGMT may not be the sole molecule determining sensitivity to TMZ in pituitary carcinomas and atypical adenomas, and that loss of MSH6 function (an enzyme involved in the mismatch repair pathway) is associated with poor responsiveness to TMZ treatment $[116,120]$.

TMZ is generally well tolerated, although patients frequently report fatigue, whereas hematological toxicity may require dose reduction or occasionally drug withdrawal. Certain concerns have been raised regarding the duration of TMZ treatment and optimal dosing. The standard regimen is $150-200 \mathrm{mg} / \mathrm{m}^{2}$ of TMZ given daily for 5 days every 28 days, but alternative regimens like 'dose-dense' protocols using $150 \mathrm{mg} / \mathrm{m}^{2}$ at days $1-7$ and days 14-21 of a 28-day cycle and 'metronomic' protocols using continuous daily low dose $\left(50-75 \mathrm{mg} / \mathrm{m}^{2}\right)$ have been used [115]. Increased risk of secondary malignancies (particularly leukemia and lymphoma) has been reported with prolonged administration of alkylating agents such as TMZ. It is currently unclear which regimen offers the best efficacy and which is associated with a reduced risk of secondary malignancy [121], whereas there are no data to support whether TMZ can be used alone or in combination with other medications such as pasireotide or capecitabine [122-124].

\section{Molecular Targeted Therapies}

Novel targeted therapies (mTOR inhibitors, antiVEGF agents) may be warranted for further investiga- tion following a case report of a patient showing disease control for 26 months after administration of the angiogenesis inhibitor bevacizumab [125] and data showing the in vitro effect of everolimus on cell viability in cell cultures from NFPAs [126]. The previously highlighted importance of EGF and its receptor EGFR has also prompted research concerning the use of tyrosine kinase inhibitors, especially the EGFR inhibitor gefitinib, as a targeted medical therapy for ACTH adenomas, demonstrating promising in vitro results [127]. There have also been some promising surgical techniques such as the implantation of Gliadel (carmustine) wafers in patients with aggressive pituitary adenomas showing stabilization or even objective responses in the majority of cases [128].

A proposed treatment algorithm for patients with aggressive pituitary tumors is illustrated in figure 3 . Because of the rarity of these tumors, data from randomized controlled studies comparing the efficacy and safety of the various therapeutic modalities are lacking, and the proposed algorithm is based on personal clinical experience and the incorporation of the findings of some of the previously reported studies. The diagnosis of an aggressive pituitary tumor can either be based on histological and genetic biomarkers detected on the adenomatous tissue after surgical removal, or on the distinct clinical course characterized by rapid growth despite the application of appropriate therapy. In case of total or neartotal resection of a tumor qualifying as an aggressive pituitary adenoma, it is prudent to apply closer imaging follow-up within 3 months in order to identify early recurrence. Patients with incompletely resected aggressive tumors may require further surgery and additional medical treatment with SSAs and/or cabergoline to control hormonal hypersecretion when present and further tumor growth; however, this is not easily achievable or sustainable. Conventional or targeted RT is considered on an individual basis taking into account patient's age, anatomical details and histopathological or molecular biomarkers of the tumor; however, no evidence-based criteria are established to identify which patients may benefit from this form of treatment. Further tumor progression should be dealt with resurgery if feasible, particularly in the presence of symptoms/signs of mass effects. Additional RT may also be applied taking into consideration radiation-induced side effects. TMZ can be offered as a palliative/salvage therapy if radiation and surgical treatments have failed to control tumor growth or are associated with increased morbidity. Early use of TMZ cannot be supported on the basis of currently exist-
98

Neuroendocrinology 2015;101:87-104 DOI: $10.1159 / 000371806$
Chatzellis/Alexandraki/Androulakis/ Kaltsas 


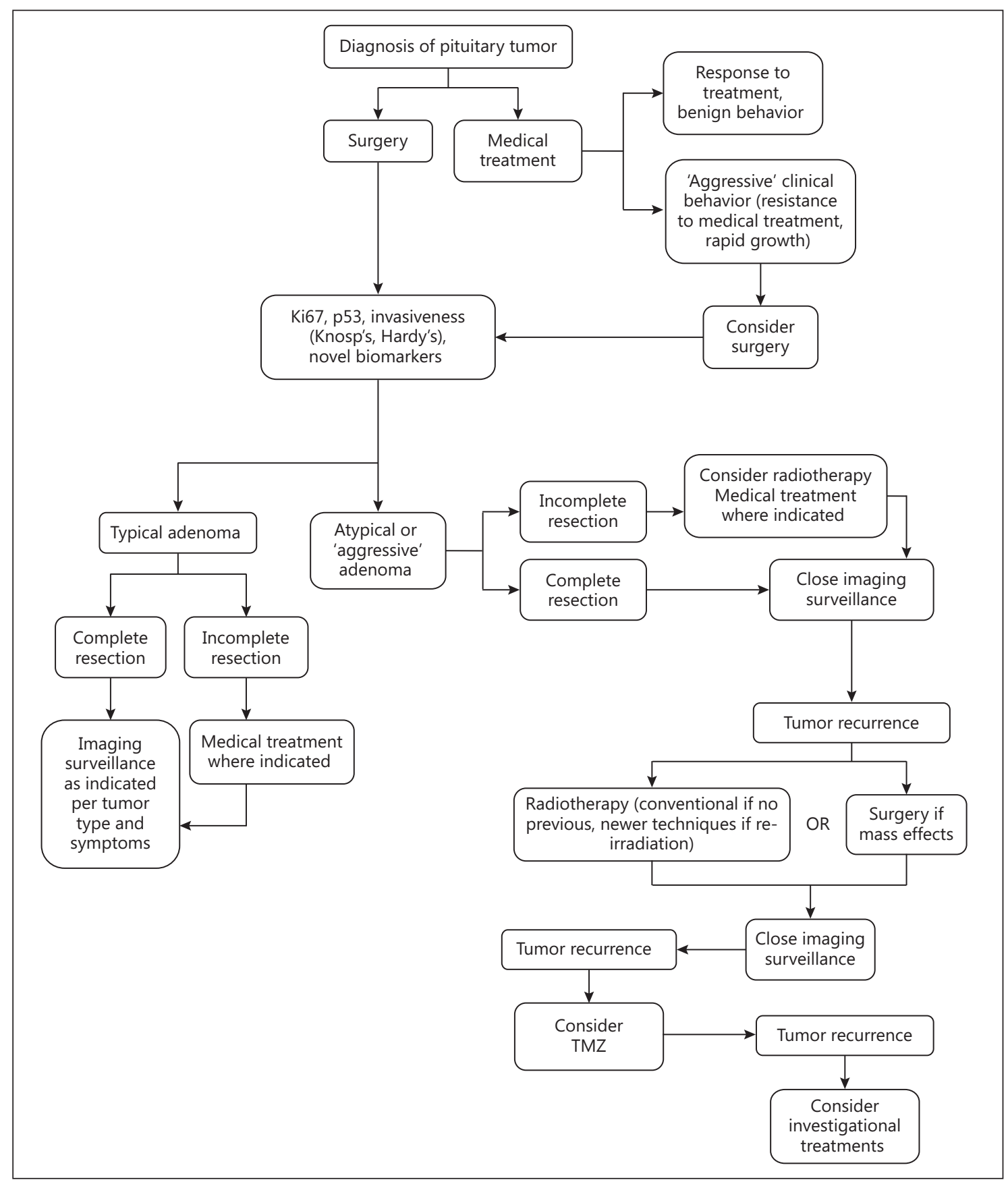

Fig. 3. Proposed algorithm for the treatment of aggressive pituitary tumors.

ing clinical data; however, this treatment can be applied in specialized centers or in the context of well-designed clinical studies. Treatments such as mTOR inhibitors, tyrosine kinase inhibitors and PRRT seem promising but can be offered as a last resort in an investigational setting.

Aggressive Pituitary Tumors

\section{Conclusion}

Aggressive pituitary adenomas constitute a challenging but not as yet clearly defined entity. Such tumors are diagnosed relatively late, respond poorly to treatment and show an overall poor prognosis. A multimodal approach taking into consideration histopathological, radiological 
and novel molecular markers seems to be the most appropriate means to identify tumors that will follow an aggressive clinical course. Registration in comprehensive and detailed databases and multicenter collaboration combined with data from long-term follow-up of patients with pituitary tumors will provide the necessary tools to develop prognostic models of aggressive behavior and apply them in order to identify such tumors. Early diagnosis will offer the chance for prompt application of intensive treatment in an attempt to reduce overall morbidity and possible progression to carcinomas. Traditional treatment agents are usually ineffective, and TMZ is currently the only agent that has shown promising results when used as a salvage therapy, although confirmation from prospective randomized control trials is lacking. Additional research on the role of MGMT and other parameters affecting responsiveness to TMZ is also needed to better predict therapeutic results and select patients who will benefit most. New drugs targeting specific pathways involved in pituitary tumorigenesis are currently under investigation and, together with new modalities of radiotherapy and radionuclide therapy, will hopefully improve outcome of these patients. Better knowledge of the precise molecular derangements in aggressive pituitary adenomas should allow the development of new targeted drugs in the future.

\section{References}

1 Kaltsas GA, Nomikos P, Kontogeorgos G, Buchfelder M, Grossman AB: Clinical review: diagnosis and management of pituitary carcinomas. J Clin Endocrinol Metab 2005;90: 3089-3099.

2 Fernandez A, Karavitaki N, Wass JA: Prevalence of pituitary adenomas: a communitybased, cross-sectional study in Banbury (Oxfordshire, UK). Clin Endocrinol 2010;72: 377-382.

-3 Daly AF, Rixhon M, Adam C, Dempegioti A, Tichomirowa MA, Beckers A: High prevalence of pituitary adenomas: a cross-sectional study in the province of Liege, Belgium. J Clin Endocrinol Metab 2006;91: 4769-4775.

-4 Selman WR, Laws ER Jr, Scheithauer BW, Carpenter SM: The occurrence of dural invasion in pituitary adenomas. J Neurosurg 1986; 64:402-407.

5 Thapar K, Kovacs K, Scheithauer BW, Stefaneanu L, Horvath E, Pernicone PJ, Murray D, Laws ER Jr: Proliferative activity and invasiveness among pituitary adenomas and carcinomas: an analysis using the MIB-1 antibody. Neurosurgery 1996;38:99-106; discussion 106-107.

-6 Scheithauer BW, Kurtkaya-Yapicier O, Kovacs KT, Young WF Jr, Lloyd RV: Pituitary carcinoma: a clinicopathological review. Neurosurgery 2005;56:1066-1074; discussion 1066-1074.

7 Lloyd RV KK, Young WF Jr, Farrel WE, Asa SL, Truillas J, Kontogeorgos G, Sano T, Scheithauer BW, Horvath E, DeLellis RA, Heitz PU: Pituitary tumors; in WHO Classification of Tumors of the Endocrine Organs: Pathology and Genetics of Endocrine Organs. Lyon, IARC Press, 2004.

8 Thapar K, Scheithauer BW, Kovacs K, Pernicone PJ, Laws ER Jr: P53 expression in pituitary adenomas and carcinomas: correlation with invasiveness and tumor growth frac- tions. Neurosurgery 1996;38:765-770; discussion 770-761.

-9 Wolfsberger S, Knosp E: Comments on the WHO 2004 classification of pituitary tumors. Acta Neuropathol 2006;111:66-67.

10 Trouillas J, Roy P, Sturm N, et al: A new prognostic clinicopathological classification of pituitary adenomas: a multicentric case-control study of 410 patients with 8 years post-operative follow-up. Acta Neuropathol 2013;126: 123-135.

11 Raverot G, Jouanneau E, Trouillas J: Management of endocrine disease: clinicopathological classification and molecular markers of pituitary tumours for personalized therapeutic strategies. Eur J Endocrinol 2014;170: R121-R132.

12 Meij BP, Lopes MB, Ellegala DB, Alden TD, Laws ER Jr: The long-term significance of microscopic dural invasion in 354 patients with pituitary adenomas treated with transsphenoidal surgery. J Neurosurg 2002;96:195-208.

$\checkmark 13$ Salehi F, Agur A, Scheithauer BW, Kovacs K, Lloyd RV, Cusimano M: Ki-67 in pituitary neoplasms: a review - part I. Neurosurgery 2009;65:429-437; discussion 437.

14 Heaney A: Management of aggressive pituitary adenomas and pituitary carcinomas. J Neurooncol 2014;117:459-468.

15 Hardy J: Transphenoidal microsurgery of the normal and pathological pituitary. Clin Neurosurg 1969;16:185-217.

16 Knosp E, Steiner E, Kitz K, Matula C: Pituitary adenomas with invasion of the cavernous sinus space: a magnetic resonance imaging classification compared with surgical findings. Neurosurgery 1993;33:610-617; discussion 617-618.

17 Phillips J, East HE, French SE, Melcescu E, Hamilton RD, Nicholas WC, Fratkin JF, Parent AD, Luzardo G, Koch CA: What causes a prolactinoma to be aggressive or to become a pituitary carcinoma? Hormones 2012;11: 477-482.
18 Mamelak AN, Carmichael JD, Park P, Bannykh S, Fan X, Bonert HV: Atypical pituitary adenoma with malignant features. Pituitary 2011;14:92-97.

19 Saeger W, Ludecke DK, Buchfelder M, Fahlbusch R, Quabbe HJ, Petersenn S: Pathohistological classification of pituitary tumors: 10 years of experience with the german pituitary tumor registry. Eur J Endocrinol 2007;156: 203-216.

20 Zada G, Woodmansee WW, Ramkissoon S, Amadio J, Nose V, Laws ER Jr: Atypical pituitary adenomas: incidence, clinical characteristics, and implications. J Neurosurg 2011; 114:336-344.

21 Yildirim AE, Divanlioglu D, Nacar OA, Dursun E, Sahinoglu M, Unal T, Belen AD: Incidence, hormonal distribution and postoperative follow up of atypical pituitary adenomas. Turk Neurosurg 2013;23:226-231.

22 Melmed S: Pathogenesis of pituitary tumors. Nat Rev Endocrinol 2011;7:257-266.

23 Dworakowska D, Grossman AB: The pathophysiology of pituitary adenomas. Best Pract Res Clin Endocrinol Metab 2009;23:525-541.

24 Al-Shraim M, Asa SL: The 2004 World Health Organization Classification of Pituitary Tumors: what is new? Acta Neuropathol 2006; 111:1-7.

25 Mete O, Ezzat S, Asa SL: Biomarkers of aggressive pituitary adenomas. J Mol Endocrinol 2012;49:R69-R78.

26 Delgrange E, Trouillas J, Maiter D, Donckier J, Tourniaire J: Sex-related difference in the growth of prolactinomas: a clinical and proliferation marker study. J Clin Endocrinol Metab 1997;82:2102-2107.

27 Heaney AP: Clinical review: pituitary carcinoma: difficult diagnosis and treatment. J Clin Endocrinol Metab 2011;96:3649-3660.

28 Kontogeorgos G: Predictive markers of pituitary adenoma behavior. Neuroendocrinology 2006;83:179-188. 
29 Cross SS, Start RD, Smith JH: Does delay in fixation affect the number of mitotic figures in processed tissue? J Clin Pathol 1990;43: 597-599.

- 30 Kovacs K: The 2004 WHO Classification of Pituitary Tumors: comments. Acta Neuropathol 2006;111:62-63.

-31 Harris CC, Hollstein M: Clinical implications of the p53 tumor-suppressor gene. N Engl J Med 1993;329:1318-1327.

- 32 Salehi F, Agur A, Scheithauer BW, Kovacs K, Lloyd RV, Cusimano M: Biomarkers of pituitary neoplasms: a review (part II). Neurosurgery 2010;67:1790-1798; discussion 1798.

- 33 Gejman R, Swearingen B, Hedley-Whyte ET: Role of Ki-67 proliferation index and p53 expression in predicting progression of pituitary adenomas. Hum Pathol 2008;39:758766.

- 34 Di Ieva A, Rotondo F, Syro LV, Cusimano $\mathrm{MD}$, Kovacs K: Aggressive pituitary adenomas - diagnosis and emerging treatments. Nat Rev Endocrinol 2014;10:423-435.

35 Pack SD, Qin LX, Pak E, Wang Y, Ault DO, Mannan P, Jaikumar S, Stratakis CA, Oldfield EH, Zhuang Z, Weil RJ: Common genetic changes in hereditary and sporadic pituitary adenomas detected by comparative genomic hybridization. Genes Chromosomes Cancer 2005;43:72-82.

- 36 Pack SD, Kirschner LS, Pak E, Zhuang Z, Carney JA, Stratakis CA: Genetic and histologic studies of somatomammotropic pituitary tumors in patients with the 'complex of spotty skin pigmentation, myxomas, endocrine overactivity and schwannomas' (Carney complex). J Clin Endocrinol Metab 2000; 85:3860-3865.

- 37 Weil RJ, Vortmeyer AO, Huang S, Boni R, Lubensky IA, Pack S, Marx SJ, Zhuang Z, Oldfield EH: 11q13 allelic loss in pituitary tumors in patients with multiple endocrine neoplasia syndrome type 1. Clin Cancer Res 1998;4: 1673-1678.

- 38 Wierinckx A, Roche M, Raverot G, LegrasLachuer C, Croze S, Nazaret N, Rey C, Auger C, Jouanneau E, Chanson P, Trouillas J, Lachuer J: Integrated genomic profiling identifies loss of chromosome 11p impacting transcriptomic activity in aggressive pituitary PRL tumors. Brain Pathol 2011;21:533-543.

- 39 Ludecke DK, Beck-Bornholdt HP, Saeger W, Schmidt W: Tumour ploidy in DNA histograms of pituitary adenomas. Acta Neurochirurg 1985;76:18-22.

-40 Galland F, Lacroix L, Saulnier P, Dessen P, Meduri G, Bernier M, Gaillard S, Guibourdenche J, Fournier T, Evain-Brion D, Bidart JM, Chanson P: Differential gene expression profiles of invasive and non-invasive nonfunctioning pituitary adenomas based on microarray analysis. Endocr Relat Cancer 2010; 17:361-371

-41 Lan L, Han H, Zuo H, Chen Z, Du Y, Zhao W, $\mathrm{Gu}$ J, Zhang Z: Upregulation of myosin Va by Snail is involved in cancer cell migration and metastasis. Int J Cancer 2010;126:53-64.
42 Gadelha MR, Trivellin G, Hernandez Ramirez LC, Korbonits M: Genetics of pituitary adenomas. Front Horm Res 2013;41:111-140.

43 Syro LV, Scheithauer BW, Kovacs K, Toledo RA, Londono FJ, Ortiz LD, Rotondo F, Horvath $\mathrm{E}$, Uribe $\mathrm{H}$ : Pituitary tumors in patients with MEN1 syndrome. Clinics (Sao Paulo) 2012;67(suppl 1):43-48.

44 Trouillas J, Labat-Moleur F, Sturm N, Kujas M, Heymann MF, Figarella-Branger D, Patey M, Mazucca M, Decullier E, Verges B, Chabre O, Calender A, Groupe d'etudes des Tumeurs E: Pituitary tumors and hyperplasia in multiple endocrine neoplasia type 1 syndrome (MEN1): a case-control study in a series of 77 patients versus 2509 non-MEN1 patients. Am J Surg Pathol 2008;32:534-543.

45 Toledo SP, Lourenco DM Jr, Toledo RA: A differential diagnosis of inherited endocrine tumors and their tumor counterparts. Clinics (Sao Paulo) 2013;68:1039-1056.

46 Palumbo T, Faucz FR, Azevedo M, Xekouki P, Iliopoulos D, Stratakis CA: Functional screen analysis reveals miR-26b and miR-128 as central regulators of pituitary somatomammotrophic tumor growth through activation of the PTEN-AKT pathway. Oncogene 2013;32: 1651-1659.

47 Amaral FC, Torres N, Saggioro F, Neder L, Machado HR, Silva WA Jr, Moreira AC, Castro M: MicroRNAs differentially expressed in ACTH-secreting pituitary tumors. J Clin Endocrinol Metab 2009;94:320-323.

48 Bottoni A, Piccin D, Tagliati F, Luchin A, Zatelli MC, degli Uberti EC: miR-15a and miR16-1 down-regulation in pituitary adenomas. J Cell Physiol 2005;204:280-285.

49 Polyak K, Lee M-H, Erdjument-Bromage H, Koff A, Roberts JM, Tempst P, Massagué J: Cloning of p27Kip1, a cyclin-dependent kinase inhibitor and a potential mediator of extracellular antimitogenic signals. Cell 1994;78:59-66.

50 Jin L, Qian X, Kulig E, Sanno N, Scheithauer BW, Kovacs K, Young WF Jr, Lloyd RV: Transforming growth factor-beta, transforming growth factor-beta receptor II, and p27kip1 expression in nontumorous and neoplastic human pituitaries. Am J Pathol 1997; 151:509-519.

51 Korbonits M, Chahal HS, Kaltsas G, Jordan S, Urmanova Y, Khalimova Z, Harris PE, Farrell WE, Claret FX, Grossman AB: Expression of phosphorylated p27(Kip1) protein and Jun activation domain-binding protein 1 in human pituitary tumors. J Clin Endocrinol Metab 2002;87:2635-2643.

52 Chesnokova V, Zonis S, Kovacs K, Ben-Shlomo A, Wawrowsky K, Bannykh S, Melmed S: P21(Cip1) restrains pituitary tumor growth. Proc Natl Acad Sci USA 2008;105:1749817503.

53 Chesnokova V, Zonis S, Zhou C, Ben-Shlomo A, Wawrowsky K, Toledano Y, Tong Y, Kovacs $K$, Scheithauer B, Melmed S: Lineagespecific restraint of pituitary gonadotroph cell adenoma growth. PLoS One 2011; 6:e17924.
54 Collado M, Serrano M: The power and the promise of oncogene-induced senescence markers. Nat Rev Cancer 2006;6:472-476.

55 Alexandraki KI, Munayem Khan M, Chahal HS, Dalantaeva NS, Trivellin G, Berney DM, Caron P, Popovic V, Pfeifer M, Jordan S, Korbonits M, Grossman AB: Oncogene-induced senescence in pituitary adenomas and carcinomas. Hormones 2012;11:297-307.

56 Duong CV, Emes RD, Wessely F, Yacqub-Usman K, Clayton RN, Farrell WE: Quantitative, genome-wide analysis of the DNA methylome in sporadic pituitary adenomas. Endocr Relat Cancer 2012;19:805-816.

57 Farrell WE, Clayton RN: Epigenetic change in pituitary tumorigenesis. Endocr Relat Cancer 2003;10:323-330.

58 Pei L, Melmed S, Scheithauer B, Kovacs K, Benedict WF, Prager D: Frequent loss of heterozygosity at the retinoblastoma susceptibility gene (RB) locus in aggressive pituitary tumors: evidence for a chromosome 13 tumor suppressor gene other than RB. Cancer Res 1995;55:1613-1616.

59 Chesnokova V, Kovacs K, Castro AV, Zonis S, Melmed S: Pituitary hypoplasia in $\mathrm{Pttg}^{-/}$ mice is protective for $\mathrm{Rb}^{+/-}$pituitary tumorigenesis. Mol Endocrinol (Baltimore) 2005;19: 2371-2379.

60 Pei L, Melmed S: Isolation and characterization of a pituitary tumor-transforming gene (PTTG). Mol Endocrinol (Baltimore) 1997; 11:433-441.

61 Filippella M, Galland F, Kujas M, Young J, Faggiano A, Lombardi G, Colao A, Meduri G, Chanson P: Pituitary tumour transforming gene (PTTG) expression correlates with the proliferative activity and recurrence status of pituitary adenomas: a clinical and immunohistochemical study. Clin Endocrinol 2006; 65:536-543.

62 Peng $\mathrm{H}$, Fan J, Wu J, Lang J, Wang J, Liu H, Zhao S, Liao J: Silencing of HEPN1 is responsible for the aggressive biological behavior of pituitary somatotroph adenomas. Cell Physiol Biochem 2013;31:379-388.

63 Sanchez-Ortiga R, Sanchez-Tejada L, Moreno-Perez O, Riesgo P, Niveiro M, Pico Alfonso AM: Over-expression of vascular endothelial growth factor in pituitary adenomas is associated with extrasellar growth and recurrence. Pituitary 2013;16:370-377.

64 LeRiche VK, Asa SL, Ezzat S: Epidermal growth factor and its receptor (EGF-R) in human pituitary adenomas: EGF-R correlates with tumor aggressiveness. J Clin Endocrinol Metab 1996;81:656-662.

65 Ezzat S, Smyth HS, Ramyar L, Asa SL: Heterogenous in vivo and in vitro expression of basic fibroblast growth factor by human pituitary adenomas. J Clin Endocrinol Metab 1995;80:878-884. 
66 Qian ZR, Sano T, Asa SL, Yamada S, Horiguchi H, Tashiro T, Li CC, Hirokawa M, Kovacs K, Ezzat S: Cytoplasmic expression of fibroblast growth factor receptor-4 in human pituitary adenomas: relation to tumor type, size, proliferation, and invasiveness. J Clin Endocrinol Metab 2004;89:1904-1911.

-67 Liu W, Matsumoto Y, Okada M, Miyake K, Kunishio K, Kawai N, Tamiya T, Nagao S: Matrix metalloproteinase 2 and 9 expression correlated with cavernous sinus invasion of pituitary adenomas. J Med Invest 2005;52: 151-158.

-68 Hussaini IM, Trotter C, Zhao Y, Abdel-Fattah R, Amos S, Xiao A, Agi CU, Redpath GT, Fang Z, Leung GK, Lopes MB, Laws ER Jr: Matrix metalloproteinase- 9 is differentially expressed in nonfunctioning invasive and noninvasive pituitary adenomas and increases invasion in human pituitary adenoma cell line. Am J Pathol 2007;170:356-365.

69 Gong J, Zhao Y, Abdel-Fattah R, Amos S, Xiao A, Lopes MB, Hussaini IM, Laws ER: Matrix metalloproteinase-9, a potential biological marker in invasive pituitary adenomas. Pituitary 2008;11:37-48.

-70 Trouillas J, Daniel L, Guigard MP, Tong S, Gouvernet J, Jouanneau E, Jan M, Perrin G, Fischer G, Tabarin A, Rougon G, FigarellaBranger D: Polysialylated neural cell adhesion molecules expressed in human pituitary tumors and related to extrasellar invasion. J Neurosurg 2003;98:1084-1093.

71 Righi A, Morandi L, Leonardi E, Farnedi A, Marucci G, Sisto A, Frank G, Faustini-Fustini M, Zoli M, Mazzatenta D, Agati R, Foschini MP: Galectin-3 expression in pituitary adenomas as a marker of aggressive behavior. Hum Pathol 2013;44:2400-2409.

72 Kaltsas GA, Grossman AB: Malignant pituitary tumours. Pituitary 1998;1:69-81.

-73 Jaffrain-Rea ML, Di Stefano D, Minniti G, Esposito V, Bultrini A, Ferretti E, Santoro A, Faticanti Scucchi L, Gulino A, Cantore G: A critical reappraisal of MIB-1 labelling index significance in a large series of pituitary tumours: secreting versus non-secreting adenomas. Endocr Relat Cancer 2002;9:103-113.

-74 Scheithauer BW, Kovacs KT, Laws ER Jr, Randall RV: Pathology of invasive pituitary tumors with special reference to functional classification. J Neurosurg 1986;65:733-744.

75 Raffin-Sanson ML, Massias JF, Dumont C, Raux-Demay MC, Proeschel MF, Luton JP, Bertagna X: High plasma proopiomelanocortin in aggressive adrenocorticotropin-secreting tumors. J Clin Endocrinol Metab 1996;81: 4272-4277.

76 Molitch ME: Management of medically refractory prolactinoma. J Neurooncol 2014; 117:421-428

77 Filopanti M, Barbieri AM, Angioni AR, Colao A, Gasco V, Grottoli S, Peri A, Baglioni S, Fustini MF, Pigliaru F, Monte PD, Borretta G, Ambrosi B, Jaffrain-Rea ML, Gasperi M, Brogioni S, Cannavo S, Mantovani G, BeckPeccoz P, Lania A, Spada A: Dopamine D2 receptor gene polymorphisms and response to cabergoline therapy in patients with prolactin-secreting pituitary adenomas. Pharmacogenomics J 2008;8:357-363.

78 Abe T, Ludecke DK: Effects of preoperative octreotide treatment on different subtypes of $90 \mathrm{GH}$-secreting pituitary adenomas and outcome in one surgical centre. Eur J Endocrinol 2001;145:137-145.

79 Fougner SL, Bollerslev J, Svartberg J, Oksnes M, Cooper J, Carlsen SM: Preoperative octreotide treatment of acromegaly. Long-term results of a randomized controlled trial. Eur J Endocrinol 2014;171:229-235.

80 Li ZQ, Quan Z, Tian HL, Cheng M: Preoperative lanreotide treatment improves outcome in patients with acromegaly resulting from invasive pituitary macroadenoma. J Int Med Res 2012;40:517-524.

-81 Fougner SL, Casar-Borota O, Heck A, Berg JP, Bollerslev J: Adenoma granulation pattern correlates with clinical variables and effect of somatostatin analogue treatment in a large series of patients with acromegaly. Clin Endocrinol 2012;76:96-102.

82 Alexandraki KI, Kaltsas GA, Isidori AM, Storr HL, Afshar F, Sabin I, Akker SA, Chew SL, Drake WM, Monson JP, Besser GM, Grossman $A B$ : Long-term remission and recurrence rates in Cushing's disease: predictive factors in a single-centre study. Eur J Endocrinol 2013; 168:639-648.

83 Kelly DF: Transsphenoidal surgery for Cushing's disease: a review of success rates, remission predictors, management of failed surgery, and nelson's syndrome. Neurosurg Focus 2007;23:E5.

84 Feelders RA, Hofland LJ: Medical treatment of Cushing's disease. J Clin Endocrinol Metab 2013;98:425-438.

85 Bertagna X, Pivonello R, Fleseriu M, Zhang Y, Robinson P, Taylor A, Watson CE, Maldonado M, Hamrahian AH, Boscaro M, Biller BM: Lci699, a potent 11beta-hydroxylase inhibitor, normalizes urinary cortisol in patients with Cushing's disease: results from a multicenter, proof-of-concept study. J Clin Endocrinol Metab 2014;99:1375-1383.

86 Pereira MAA, Halpern A, Salgado LR, Mendonça BB, Nery M, Liberman B, Streeten DHP, Wajchenberg BL: A study of patients with Nelson's syndrome. Clin Endocrinol 1998;49:533-539.

87 Beck-Peccoz P, Persani L, Mannavola D, Campi I: Pituitary tumours: Tsh-secreting adenomas. Best Pract Res Clin Endocrinol Metab 2009;23:597-606.

88 Ezzat S, Horvath E, Kovacs K, Smyth HS, Singer W, Asa SL: Basic fibroblast growth factor expression by two prolactin and thyrotropin-producing pituitary adenomas. Endocr Pathol 1995;6:125-134.

89 Webster J, Peters JR, John R, Smith J, Chan V, Hall R, Scanlon MF: Pituitary stone: two cases of densely calcified thyrotrophin-secreting pituitary adenomas. Clin Endocrinol 1994;40: 137-143.
-90 Beck-Peccoz P, Lania A, Beckers A, Chatterjee K, Wemeau JL: 2013 European thyroid association guidelines for the diagnosis and treatment of thyrotropin-secreting pituitary tumors. Eur Thyroid J 2013;2:76-82.

91 Beck-Peccoz P, Brucker-Davis F, Persani L, et al: Thyrotropin-secreting pituitary tumors. Endocr Rev 1996;17:610-638.

92 Chang E, Sughrue M, Zada G, Wilson C, Blevins L Jr, Kunwar S: Long term outcome following repeat transsphenoidal surgery for recurrent endocrine-inactive pituitary adenomas. Pituitary 2010;13:223-229.

93 Benveniste RJ, King WA, Walsh J, Lee JS, Delman BN, Post KD: Repeated transsphenoidal surgery to treat recurrent or residual pituitary adenoma. J Neurosurg 2005;102: 1004-1012.

\$4 Patil CG, Veeravagu A, Prevedello DM, Katznelson L, Vance ML, Laws ER Jr: Outcomes after repeat transsphenoidal surgery for recurrent Cushing's disease. Neurosurgery 2008;63:266-270; discussion 270271.

$\$ 95$ Buchfelder M: Management of aggressive pituitary adenomas: current treatment strategies. Pituitary 2009;12:256-260.

96 Raverot G, Castinetti F, Jouanneau E, Morange I, Figarella-Branger D, Dufour $\mathrm{H}$ Trouillas J, Brue T: Pituitary carcinomas and aggressive pituitary tumours: merits and pitfalls of temozolomide treatment. Clin Endocrinol 2012;76:769-775.

-97 Prasad D: Clinical results of conformal radiotherapy and radiosurgery for pituitary adenoma. Neurosurg Clin North Am 2006; 17:129-141, vi.

98 Gittoes NJ: Radiotherapy for non-functioning pituitary tumors - when and under what circumstances? Pituitary 2003;6:103108.

99 Kopp C, Theodorou M, Poullos N, Jacob V, Astner ST, Molls M, Grosu AL: Tumor shrinkage assessed by volumetric MRI in long-term follow-up after fractionated stereotactic radiotherapy of nonfunctioning pituitary adenoma. Int J Radiat Oncol Biol Physics 2012;82:1262-1267.

100 Sheehan JP, Niranjan A, Sheehan JM, Jane JA Jr, Laws ER, Kondziolka D, Flickinger J, Landolt AM, Loeffler JS, Lunsford LD: Stereotactic radiosurgery for pituitary adenomas: an intermediate review of its safety, efficacy, and role in the neurosurgical treatment armamentarium. J Neurosurg 2005; 102:678-691.

101 Castinetti F, Regis J, Dufour H, Brue T: Role of stereotactic radiosurgery in the management of pituitary adenomas. Nat Rev Endocrinol 2010;6:214-223.

102 Mountcastle RB, Roof BS, Mayfield RK, Mordes DB, Sagel J, Biggs PJ, Rawe SE: Pituitary adenocarcinoma in an acromegalic patient: response to bromocriptine and pituitary testing: a review of the literature on 36 cases of pituitary carcinoma. Am J Med Sci 1989;298:109-118. 
-103 Rowe J, Grainger A, Walton L, Silcocks P, Radatz M, Kemeny A: Risk of malignancy after gamma knife stereotactic radiosurgery. Neurosurgery 2007;60:60-65; discussion 65-66.

104 Verma J, McCutcheon IE, Waguespack SG, Mahajan A: Feasibility and outcome of reirradiation in the treatment of multiply recurrent pituitary adenomas. Pituitary 2014; 17:539-545.

105 Swords FM, Monson JP, Besser GM, Chew SL, Drake WM, Grossman AB, Plowman PN: Gamma knife radiosurgery: a safe and effective salvage treatment for pituitary tumours not controlled despite conventional radiotherapy. Eur J Endocrinol 2009;161: 819-828.

106 Kwekkeboom DJ, de Herder WW, Kam BL, van Eijck $\mathrm{CH}$, van Essen $\mathrm{M}$, Kooij PP, Feelders RA, van Aken MO, Krenning EP: Treatment with the radiolabeled somatostatin analog [177 lu-dota 0, tyr3]octreotate: toxicity, efficacy, and survival. J Clin Oncol 2008;26:2124-2130.

-107 Baldari S, Ferrau F, Alafaci C, Herberg A, Granata F, Militano V, Salpietro FM, Trimarchi F, Cannavo S: First demonstration of the effectiveness of peptide receptor radionuclide therapy (PRRT) with 111in-DTPAoctreotide in a giant PRL-secreting pituitary adenoma resistant to conventional treatment. Pituitary 2012;15(suppl 1):S57-S60.

108 Komor J, Reubi JC, Christ ER: Peptide receptor radionuclide therapy in a patient with disabling non-functioning pituitary adenoma. Pituitary 2014;17:227-231.

109 Maclean J, Aldridge M, Bomanji J, Short S, Fersht N: Peptide receptor radionuclide therapy for aggressive atypical pituitary adenoma/carcinoma: variable clinical response in preliminary evaluation. Pituitary 2014; 17:530-538.

-110 Kaltsas GA, Mukherjee JJ, Plowman PN, Monson JP, Grossman AB, Besser GM: The role of cytotoxic chemotherapy in the management of aggressive and malignant pituitary tumors. J Clin Endocrinol Metab 1998; 83:4233-4238.

111 Vaughan NJ, Laroche CM, Goodman I, Davies MJ, Jenkins JS: Pituitary Cushing's disease arising from a previously non-functional corticotrophic chromophobe adenoma. Clin Endocrinol 1985;22:147-153.

-112 Kasperlik-Zaluska AA, Wislawski J, Kaniewska J, Zborzil J, Frankiewicz E, Zgliczynski S: Cytostatics for acromegaly. Marked improvement in a patient with an invasive pituitary tumour. Acta Endocrinol 1987;116:347-349.

113 Raverot G, Sturm N, de Fraipont F, et al: Temozolomide treatment in aggressive pituitary tumors and pituitary carcinomas: a French multicenter experience. J Clin Endocrinol Metab 2010;95:4592-4599.

-114 Losa M, Mazza E, Terreni MR, McCormack A, Gill AJ, Motta M, Cangi MG, Talarico A, Mortini P, Reni M: Salvage therapy with te- mozolomide in patients with aggressive or metastatic pituitary adenomas: experience in six cases. Eur J Endocrinol 2010;163:843851.

-115 Bush ZM, Longtine JA, Cunningham T, Schiff D, Jane JA Jr, Vance ML, Thorner MO, Laws ER Jr, Lopes MB: Temozolomide treatment for aggressive pituitary tumors: correlation of clinical outcome with $0^{6}$ methylguanine methyltransferase (MGMT) promoter methylation and expression. J Clin Endocrinol Metab 2010;95:E280-E290.

116 Hirohata T, Asano K, Ogawa Y, Takano S, Amano K, Isozaki O, Iwai Y, Sakata K, Fukuhara N, Nishioka H, Yamada S, Fujio S, Arita K, Takano K, Tominaga A, Hizuka N, Ikeda H, Osamura RY, Tahara S, Ishii Y, Kawamata T, Shimatsu A, Teramoto A, Matsuno A: DNA mismatch repair protein (MSH6) correlated with the responses of atypical pituitary adenomas and pituitary carcinomas to temozolomide: the national cooperative study by the Japan Society for Hypothalamic and Pituitary Tumors. J Clin Endocrinol Metab 2013;98:1130-1136.

-117 Kovacs K, Horvath E, Syro LV, Uribe H, Penagos LC, Ortiz LD, Fadul CE: Temozolomide therapy in a man with an aggressive prolactin-secreting pituitary neoplasm: morphological findings. Hum Pathol 2007; 38:185-189.

118 Syro LV, Scheithauer BW, Ortiz LD, Fadul CE, Horvath E, Rotondo F, Kovacs K: Effect of temozolomide in a patient with recurring oncocytic gonadotrophic pituitary adenoma. Hormones 2009;8:303-306.

119 Salehi F, Scheithauer BW, Kros JM, Lau Q, Fealey M, Erickson D, Kovacs K, Horvath E, Lloyd RV: MGMT promoter methylation and immunoexpression in aggressive pituitary adenomas and carcinomas. J Neurooncol 2011;104:647-657.

120 Matsuno A, Murakami M, Hoya K, Yamada SM, Miyamoto S, Yamada S, Son JH, Nishido H, Ide F, Nagashima H, Sugaya M, Hirohata T, Mizutani A, Okinaga H, Ishii Y, Tahara S, Teramoto A, Osamura RY: Molecular status of pituitary carcinoma and atypical adenoma that contributes the effectiveness of temozolomide. Med Mol Morphol 2014;47:1-7.

121 McCormack AI, Wass JA, Grossman AB: Aggressive pituitary tumours: the role of temozolomide and the assessment of MGMT status. Eur J Clin Invest 2011;41:1133-1148.

122 Zacharia BE, Gulati AP, Bruce JN, Carminucci AS, Wardlaw SL, Siegelin M, Remotti H, Lignelli A, Fine RL: High response rates and prolonged survival in patients with corticotroph pituitary tumors and refractory Cushing disease from capecitabine and temozolomide (CAPTEM): a case series. Neurosurgery 2014;74:E447-E455; discussion E455.

123 Thearle MS, Freda PU, Bruce JN, Isaacson SR, Lee Y, Fine RL: Temozolomide (temodar(r)) and capecitabine (xeloda(r)) treat- ment of an aggressive corticotroph pituitary tumor. Pituitary 2011;14:418-424.

124 Bode H, Seiz M, Lammert A, Brockmann MA, Back W, Hammes HP, Thome C: Som230 (pasireotide) and temozolomide achieve sustained control of tumour progression and ACTH secretion in pituitary carcinoma with widespread metastases. Exp Clin Endocrinol Diabetes 2010;118:760763.

125 Ortiz LD, Syro LV, Scheithauer BW, Ersen A, Uribe H, Fadul CE, Rotondo F, Horvath E, Kovacs K: Anti-VEGF therapy in pituitary carcinoma. Pituitary 2012;15:445-449.

126 Zatelli MC, Minoia M, Filieri C, Tagliati F, Buratto M, Ambrosio MR, Lapparelli M, Scanarini M, Degli Uberti EC: Effect of everolimus on cell viability in nonfunctioning pituitary adenomas. J Clin Endocrinol Metab 2010;95:968-976.

- 127 Fukuoka H, Cooper O, Ben-Shlomo A, Mamelak A, Ren SG, Bruyette D, Melmed S: EGFR as a therapeutic target for human, canine, and mouse ACTH-secreting pituitary adenomas. J Clin Invest 2011;121:47124721.

128 Laws ER Jr, Morris AM, Maartens N: Gliadel for pituitary adenomas and craniopharyngiomas. Neurosurgery 2003;53:255-269; discussion 259-260.

129 Scheithauer BW, Gaffey TA, Lloyd RV, Sebo TJ, Kovacs KT, Horvath E, Yapicier O, Young WF Jr, Meyer FB, Kuroki T, Riehle DL, Laws ER Jr: Pathobiology of pituitary adenomas and carcinomas. Neurosurgery 2006;59:341-353; discussion 341-353.

130 Syro LV, Uribe H, Penagos LC, Ortiz LD, Fadul CE, Horvath E, Kovacs K: Antitumour effects of temozolomide in a man with a large, invasive prolactin-producing pituitary neoplasm. Clin Endocrinol 2006;65:552553.

131 Lim S, Shahinian H, Maya MM, Yong W, Heaney AP: Temozolomide: a novel treatment for pituitary carcinoma. Lancet Oncol 2006;7:518-520.

132 Neff LM, Weil M, Cole A, Hedges TR, Shucart W, Lawrence D, Zhu JJ, Tischler AS, Lechan RM: Temozolomide in the treatment of an invasive prolactinoma resistant to dopamine agonists. Pituitary 2007;10:81-86.

133 Fadul CE, Kominsky AL, Meyer LP, Kingman LS, Kinlaw WB, Rhodes CH, Eskey CJ, Simmons NE: Long-term response of pituitary carcinoma to temozolomide. Report of two cases. J Neurosurg 2006;105:621-626.

134 Kovacs K, Scheithauer BW, Lombardero M, McLendon RE, Syro LV, Uribe H, Ortiz LD, Penagos LC: MGMT immunoexpression predicts responsiveness of pituitary tumors to temozolomide therapy. Acta Neuropathol 2008;115:261-262.

135 Debono M BC, Ross R, Newell-Price J: Treating an aggressive prolactinoma in a patient with MEN 1: beneficial response to temozolomide. Endocrine Abstr 2008; 15: P188. 
136 Byrne S, Karapetis C, Vrodos N: A novel use of temozolomide in a patient with malignant prolactinoma. J Clin Neurosci 2009; 16: 1694-1696.

137 Moyes VJ, Alusi G, Sabin HI, Evanson J, Berney DM, Kovacs K, Monson JP, Plowman PN, Drake WM: Treatment of nelson's syndrome with temozolomide. Eur J Endocrinol 2009;160:115-119.

138 Takeshita A, Inoshita N, Taguchi M, Okuda C, Fukuhara N, Oyama K, Ohashi K, Sano T, Takeuchi Y, Yamada S: High incidence of low $0^{6}$-methylguanine DNA methyltransferase expression in invasive macroadenomas of Cushing's disease. Eur J Endocrinol 2009; 161:553-559.

139 Hagen C, Schroeder HD, Hansen S, Hagen C, Andersen M: Temozolomide treatment of a pituitary carcinoma and two pituitary macroadenomas resistant to conventional therapy. Eur J Endocrinol 2009;161:631637.

140 McCormack AI, McDonald KL, Gill AJ, Clark SJ, Burt MG, Campbell KA, Braund WJ, Little NS, Cook RJ, Grossman AB, Robinson BG, Clifton-Bligh RJ: Low $0^{6}$-methylguanine-DNA methyltransferase (MGMT) expression and response to temozolomide in aggressive pituitary tumours. Clin Endocrinol 2009;71:226-233.
141 Curto L, Torre ML, Ferrau F, Pitini V, Altavilla G, Granata F, Longo M, Hofland LJ, Trimarchi F, Cannavo S: Temozolomide-induced shrinkage of a pituitary carcinoma causing Cushing's disease - report of a case and literature review. ScientificWorldJournal 2010;10:2132-2138.

142 Mohammed S, Kovacs K, Mason W, Smyth $\mathrm{H}$, Cusimano MD: Use of temozolomide in aggressive pituitary tumors: case report. Neurosurgery 2009;64:E773-E774; discussion E774.

143 Morokuma H, Ando T, Hayashida T, Horie I, Inoshita N, Murata F, Ueki I, Nakamura K, Imaizumi M, Usa T, Kawakami A: A case of nonfunctioning pituitary carcinoma that responded to temozolomide treatment. Case Rep Endocrinol 2012;2012:645914.

144 Annamalai AK, Dean AF, Kandasamy N, Kovacs K, Burton H, Halsall DJ, Shaw AS, Antoun NM, Cheow HK, Kirollos RW, Pickard JD, Simpson HL, Jefferies SJ, Burnet NG, Gurnell M: Temozolomide responsiveness in aggressive corticotroph tumours: a case report and review of the literature. Pituitary 2012;15:276-287.
45 Murakami M, Mizutani A, Asano S, Katakami $\mathrm{H}$, Ozawa $\mathrm{Y}$, Yamazaki $\mathrm{K}$, Ishida Y, Takano K, Okinaga H, Matsuno A: A mechanism of acquiring temozolomide resistance during transformation of atypical prolactinoma into prolactin-producing pituitary carcinoma: case report. Neurosurgery 2011;68:E1761-E1767; discussion E1767.

146 Dillard TH, Gultekin SH, Delashaw JB Jr, Yedinak CG, Neuwelt EA, Fleseriu M: Temozolomide for corticotroph pituitary adenomas refractory to standard therapy. Pituitary 2011;14:80-91.

147 Moshkin O, Syro LV, Scheithauer BW, Ortiz LD, Fadul CE, Uribe H, Gonzalez R, Cusimano M, Horvath E, Rotondo F, Kovacs K: Aggressive silent corticotroph adenoma progressing to pituitary carcinoma: the role of temozolomide therapy. Hormones 2011; $10: 162-167$

148 Hardy J: Transphenoidal surgery of hypersecreting pituitary tumors; in Kohler PO, Ross GT (eds): Diagnosis and Treatment of Pituitary Tumors. Int Congr Ser 303. Amsterdam, Excerpta Medica, 1973, pp 179-194.

149 Kovacs K, Horvath E: Tumors of the pituitary gland; in Atlas of Tumor Pathology. Washington, Armed Forces Institute of $\mathrm{Pa}$ thology, 1983, ser 2, pp 66-70. 